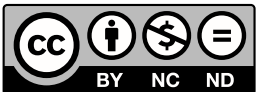

Estudos Teológicos foi licenciado com uma Licença Creative Commons Atribuição - NãoComercial - SemDerivados 3.0 Não Adaptada

http://dx.doi.org/10.22351/etv59i2.3762

\title{
O MÉTODO HISTÓRICO-CRÍTICO E A NOVA ARQUEOLOGIA: UMA ANÁLISE BÍBLICO-ARQUEOLÓGICA DO CONTEXTO HISTÓRICO do LiVRo de NeEmias ${ }^{1}$
}

\author{
The historical critical method and the new archeology: \\ a biblical-archaeological analysis of the historical context of the Nehemiah book.
}

\author{
José Ademar Kaefer ${ }^{2}$ \\ Suely Xavier ${ }^{3}$
}

\begin{abstract}
Resumo: O presente artigo apresenta uma análise do contexto histórico do livro de Neemias à luz do método histórico-crítico e das recentes descobertas e conclusões da nova arqueologia. Pela análise literária se percebe uma incongruência quanto à cronologia dos fatos históricos narrados nos livros de Neemias e Esdras, o que dificulta precisar a data da composição de ambos. Concomitantemente, a arqueologia revela que existe um grande vazio no que tange a evidências arqueológicas do período persa. Os resultados das escavações em Jerusalém e arredores colocam uma grande interrogação quanto ao tamanho da Província Jehud, do tamanho da cidade, da importância do templo, enquanto centro da coleta de tributos, da existência da muralha persa, da existência nesse período das localidades mencionadas no texto etc. A ausência de evidências arqueológicas parece apontar ainda para um grande declínio da escrita em Judá durante o reinado persa. Toda essa situação deveria colocar a comunidade acadêmica em alerta, uma vez que a pesquisa moderna tende a situar grande parte da produção bíblica no período persa.
\end{abstract}

Palavras-chave: Neemias. Método histórico-crítico. Nova arqueologia. Período persa. Jerusalém.

Abstract: This paper presents an analysis of the historical context of Nehemiah Book in light of the historical critical method and recent discoveries and conclusions of the new archeology. The literary analysis reveals an incongruity regarding to the chronology of the historical facts narrated in the books of Nehemiah and Ezra, which makes it difficult to specify the date of their composition. Concomitantly, archeology reveals that there is a great void regarding archaeological evidence of the Persian period. The

\footnotetext{
O artigo foi recebido em 30 de julho de 2019 e aprovado em 02 de agosto de 2019 com base nas avaliações dos pareceristas ad hoc.

2 Doutor. Universidade Metodista de São Paulo, São Bernardo do Campo, SP. E-mail: jademarkaefer@ gmail.com

3 Doutora. Universidade Metodista de São Paulo, São Bernardo do Campo, SP. E-mail: suelyxavier@, hotmail.com
} 
results of the excavations in and around Jerusalem pose a major question about the size of the Jehud Province, the size of the city, the importance of the temple as a center for tax collection, the existence of the Persian wall, the existence of the places mentioned in that period etc. The absence of archaeological evidence still seems to point to a great decline of writing in Judah during the Persian reign. This whole situation should alert the academic community, since modern research tends to place much of biblical production in the Persian period.

Keywords: Nehemiah. Historical critical method. New archeology. Persian period. Jerusalem.

\section{Introdução}

O método histórico-crítico (MHC) ajudou na construção de uma "ciência bíblica", pois parte do pressuposto que os textos bíblicos antes de tudo são "textos", passíveis de estudo, investigação e interpretação. Surge como intuito de usar critérios científicos no estudo objetivo dos textos bíblicos. Mas, como método, também precisa ser revisto, revisitado, reelaborado, avaliado e, à luz de outros métodos, complementado. É nesse escopo que se emprestarão as contribuições do que chamamos de nova arqueologia para a análise do contexto histórico que se encontra por trás do livro de Neemias. A contribuição da arqueologia, na qual nosso estudo se apoiará em pesquisas recentes, em particular de Israel Finkelstein, dar-se-á principalmente a partir do conteúdo geográfico do livro de Neemias. Além da referência a lugares, cidades e regiões, a análise se valerá da alusão ao grande número de personagens, como os inimigos de Neemias, presente no referido livro, identificados como pertencentes a grupos específicos de determinadas localidades. Outro referencial muito peculiar será a cidade de Jerusalém, em especial à construção da muralha, assunto preponderante no livro.

Perseguindo esse propósito, após discorrer brevemente sobre o MHC e da nova arqueologia, a pesquisa se desenvolverá pela análise dos seguintes tópicos: o problema da datação do livro de Neemias, onde se comentará a dissonância entre os livros de Neemias, Esdras e Crônicas; o vazio arqueológico do período persa, assunto "incômodo" e de amplo debate no campo da arqueologia; a extensão da província Jehud do período persa, delimitação possível graças ao estudo das pitoi encontradas em Judá; a importância de Ramat Rahel, como centro da coleta de tributo do período persa; e, por fim, a ausência de escritos extrabíblicos do período persa. Os principais textos do livro de Neemias que serão objeto de análise são: Neemias 3.1-32, que trata especificamente da reconstrução da muralha de Jerusalém, e Neemias 7.6-72, que trata da lista dos repatriados.

\section{O método histórico-crítico (MHC)}

$\mathrm{O} \mathrm{MHC}$ representa um marco na exegese bíblica. Em vez de se opor às ciências modernas, o método fez e faz uso delas para a análise do seu objeto. Isso permitiu aproximar a Bíblia e as ciências, ampliar a influência da Bíblia sobre a teologia, 
renovando-a, melhorar o diálogo entre as ciências e a teologia, alargar o diálogo ecumênico e inter-religioso etc. Por outro lado, o MHC beneficiou também o interesse dos cristãos pela leitura bíblica e ajudou a tornar a Bíblia uma ferramenta de transformação social mais efetiva. ${ }^{4}$

O MHC, porém, não está imune a críticas. A crítica mais comum é de que seja um método que permanece no passado. Outra crítica é de que o método coloca ênfase somente na dimensão humana, privilegia as ciências sociais e esquece Deus, portanto o método seria limitado no ponto de vista da fé. Além disso, o MHC faria da Bíblia um livro complexo reservado só para especialistas. ${ }^{5}$ Uma crítica mais contundente é de que o método estaria voltado só para o conteúdo originário, concentrando sua atenção unicamente na perícope, esquecendo o conjunto da obra bíblica. Isso fez com que surgissem outros métodos, como a semiótica, que teve Algirdas J. Grimas como um dos seus expoentes, a leitura canônica, que teve Brevard S. Childs como uma das suas principais referências. Métodos esses que privilegiam a análise sincrônica dos textos considerando o conjunto dos livros bíblicos. ${ }^{6}$

$\mathrm{Na}$ América Latina, a partir do $\mathrm{MHC}$ ou em reação a ele, surgiram ou criaram corpo novas abordagens bíblicas que procuram ampliar e aprofundar no estudo do MHC ou resgatar aspectos ignorados por ele. É o caso da abordagem sociológica, da antropológica, da feminista, da indígena, da negra, da pós-colonial etc. Todas elas carregam em sua essência princípios do MHC. O que evidencia que até hoje não surgiu um método que suprisse à altura o MHC. Em todo caso, a diversidade de métodos ou abordagens é uma prova da riqueza da Bíblia e de que nenhum método é capaz de abarcar o todo da Bíblia.?

\section{A nova arqueologia}

A chamada "arqueologia bíblica" nasceu nas últimas décadas do século XIX. Primeiro com a fundação em 1865 da inglesa Palestine Exploration Fund (PEF), que unia interesses religiosos aos interesses políticos do império inglês. E, um pouco mais tarde, em 1870, com a fundação estadunidense da Palestine Exploration Society (PES) e da Society of Biblical Archaeology, mais voltadas a fundamentar as verdades bíblicas frente às investidas das ciências. ${ }^{8}$ Foi com essa perspectiva que foi escavada boa parte da Palestina nas primeiras décadas do século XX. E foi assim que inicialmente

4 KAEFER, José Ademar. Hermenêutica bíblica: Refazendo caminhos. Estudos de Religião, São Bernardo do Campo, v. 28, n. 1, p. 115-134, 2014. FITZMYER, Joseph A. A Bíblia na Igreja. São Paulo: Loyola, 1997.

5 PONTIFÍCIA COMISSÃO BÍBLICA. A interpretação da Bíblia na Igreja. São Paulo: Paulinas, 1994. n. 134, p. 47-82.

6 RÖMER, Thomas; MACCHI, Jean-Daniel; NIHAN, Christophe (Orgs.). Antigo Testamento: história, escritura e teologia. São Paulo: Loyola, 2010. p. 388ss.

PONTIFÍCIA COMISSÃO BÍBLICA, 1994, p. 46.

8 DAVIS, W. Thomas. Shifting Sands: The Rise and Fall of Biblical Archaeology. New York: Oxford University Press, 2004. 
a "arqueologia bíblica" serviu de base para a análise do contexto histórico do MHC, que a partir de meados do século XX principia a reger a exegese bíblica.

Contudo, com o avanço da pesquisa, a exegese bíblica caminha em direção a uma análise mais crítica dos textos bíblicos, com a implementação de novos métodos, em particular as escolas europeias. Enquanto que a arqueologia permanecia irredutível em seus princípios fundamentalistas das "verdades bíblicas", bem como na defesa dos interesses políticos, principalmente do estado de Israel, que a partir da década de 1970 foi ganhando corpo e tomando o controle da arqueologia palestinense. Soma-se a isso o fato da maioria dos arqueólogos serem militares ou pertencerem a uma denominação religiosa. De maneira que aos poucos foi surgindo um divórcio entre a exegese bíblica e a "arqueologia bíblica", divórcio que em boa parte se mantém até hoje.

Ao redor da década de 1990, porém, grupos de arqueólogos e arqueólogas começam a praticar uma arqueologia mais crítica, sem interferência religiosa e política. Tomamos como referência o trabalho realizado pelo Departamento de Arqueologia da Universidade de Tel Aviv, coordenado pelos arqueólogos David Ussishkin e Israel Finkelstein, que tem como centro de sua pesquisa o sítio arqueológico de Meguido (Tel Megiddo). ${ }^{9}$ Elencamos a seguir alguns princípios dessa nova forma de fazer arqueologia.

- O abandono da "arqueologia bíblica". Isto é, praticar uma arqueologia crítica, que não tenha em uma mão a Bíblia e noutra a picareta.

- Concentração da pesquisa num único período. Ou seja, em vez de atentar para todos os períodos (estudo integral das camadas), concentrar a pesquisa em um período específico, no caso, do Bronze Tardio e Ferro I.

- Diminuição do espaço de tempo do estudo da estratigrafia de 100 a 200 anos para 25 anos. Isso possibilita maior precisão da datação. ${ }^{10}$

- Aumentar consideravelmente o número de amostras a analisar e realizar os testes em diferentes laboratórios, com o objetivo de diminuir o risco de erro da datação. ${ }^{11}$

- Aumentar o auxílio das ciências, como: o radiocarbono, apesar do custo elevado dos testes; o estudo do DNA antigo, importante para o mapeamento das populações; atenção ao estudo do paleoclima, como a análise de polens, para, por exemplo, estudar o caso da seca prolongada que ocorreu no final do Bronze Tardio; a análise de resíduos de moléculas impressas nos vasos; estudo dos estilos da escrita, como no caso dos ôstracos de Arad e da Samaria; exercício da paleoarqueologia, especialmente no deserto do Neguev, onde se visa ao estudo de células de plantas petrificadas/fossilizadas que guardam minerais extraídos da terra (Phytolites) e de células de material orgânico de animais/pessoas (ossos/carne) fossilizadas (Spherulites).

Todo esse empreendimento concentrado em boa parte no Tel Megiddo trouxe resultados que vêm mudando enormemente a compreensão da história do Israel bíblico.

9 USSISHKIN, David. Megiddo-Armageddon. The Story of the Canaanite and Israelite City. Jerusalém: Israel Exploration Society, 2018.

${ }^{10}$ FINKELSTEIN, Israel. The Stratigraphy and Chronology of Megiddo and Bethshan in the 12-11th Centuries B.C.E. Tel Aviv, v. 23, p. 170-184, 1996.

${ }^{11}$ Cf. KAEFER, José Ademar. Arqueologia das Terras da Bíblia. São Paulo: Paulus, 2016. v. II. 
É a partir dessa nova visão arqueológica, integrada ao $\mathrm{MHC}$, que queremos analisar o contexto histórico do livro de Neemias.

\section{O contexto literário: a contemporaneidade de Neemias e Esdras (e Crônicas?)}

Os livros de Esdras e Neemias formavam um só livro, tanto na Bíblia hebraica como na Septuaginta. Na Bíblia Hebraica, Esdras e Neemias eram denominados de "o livro de Esdras". A Septuaginta denominava o livro de Esdras e Neemias de Esdras II. Para ela, Esdras I era o livro apócrifo grego, que ela conservava. Já no início do cristianismo, o livro de Esdras virou Esdras I, o livro de Neemias virou Esdras II e o livro apócrifo grego virou Esdras III. Essa mesma ordem foi seguida pela Vulgata. ${ }^{12}$

Portanto Esdras e Neemias são duas partes de uma mesma obra, escrita pelo mesmo autor (de Crônicas?). ${ }^{13}$ Inclusive, os personagens se misturam e assim também as datas, que, aliás, é um assunto complicado para se solucionar.

O texto bíblico coloca a chegada de Esdras a Jerusalém no ano de 458 a.C. (Ed 7.8), durante o reinado de Artaxerxes (465-424), com o título tanto de sacerdote como de escriba, a serviço do governo persa (Ed 7). A função de Esdras, que teria vindo com cerca de cinco mil exilados, seria a de aplicar a lei religiosa e civil, decretada pelo império como lei para a província. Esdras, portanto, teria chegado antes de Neemias, que teria chegado entre os anos 445-433 (Ne 2.1).

Contudo, há uma grande confusão cronológica na narrativa dos dois livros. No texto aramaico de Esdras 4.6 - 6.18, as ações de Dario são situadas após o reinado de Xerxes e Artaxerxes, que reinaram na metade do século seguinte. Neemias 8.1,9 e Neemias 12.26,36 citam Esdras e Neemias como sendo contemporâneos. Seria muito estranho que os dois líderes tivessem sido designados para uma missão similar no mesmo período. É estranho também que, já no primeiro capítulo do livro, Neemias trate fortemente da lei (Ne 1.7,9), que ainda está por ser organizada. Também há informações desconexas ou repetidas nos dois livros, como a lista dos que retornam do exílio, apresentada duas vezes (Ed 2 e $\mathrm{Ne} 7)$.

De maneira que, pela narrativa dos dois livros, Esdras teria que ser posterior a Neemias, pois o livro de Neemias cita a lista de repatriados de Zorobabel (Ed 2), mas não cita a de Esdras. Neemias encontra as muralhas de Jerusalém destruídas e a cidade quase desabitada, ao passo que em Esdras, Jerusalém já prosperava dentro de suas muralhas. Neemias é contemporâneo ao sumo sacerdote Eliasib (3.1), enquanto Esdras vive no tempo do seu neto Johanam.

Uma hipótese para solucionar esse impasse é de que Esdras não teria chegado a Jerusalém no "sétimo ano de Artaxerxes I" (465-424), e sim de Artaxerxes II (404-

12 ABDIE, Philippe. Esdras-Neemias. In: ROMER; MACCHI; NIHAN, 2010, p. 701-713; BÍBLIA DE JERUSALÉM. São Paulo: Paulus, 2002. p. 547-549.

${ }^{13}$ Cf. opinião contrária em: STEINS, Georg. Os livros de Esdras e Neemias. In: ZENGER, Erich (Org.). Introdução ao Antigo Testamento. São Paulo: Loyola, 2003. p. 222-232. 
358). O que dataria a chegada de Esdras a Judá em 398-397. Outra possibilidade seria de que Esdras fosse um personagem criado pelo cronista, pois há muita similitude entre os livros de Crônicas e os de Esdras e Neemias. Ainda que, supostamente, os livros de Esdras e Neemias sejam anteriores aos livros de Crônicas, contudo, os três livros têm textos em comum, como as listas dos repatriados e da população de Jerusalém, a prestação de contas da missão de Esdras, as cartas do rei persa, as ações da corte persa etc. Além de que a conclusão do livro de Crônicas é literalmente a introdução do livro de Esdras (2Cr 36.22-23; Ed 1.1-3). Ainda, às vezes, dá a impressão de que Neemias é um personagem similar a Daniel, ambos são funcionários da corte do império, um da Babilônia e outro da Pérsia.

Tudo isso coloca uma grande interrogação quanto à data da composição do livro de Neemias e, por extensão, dos livros de Esdras e Crônicas. Não é estranho pensar que o cronista, sem dominar a ordem cronológica dos fatos históricos, tenha tomado informações a partir das memórias do personagem Neemias, narradas em primeira pessoa ( $\mathrm{Ne} 1.1-2.20 ; 3.33-7.5 ; 12.31-43 ; 13.4-31)$ e acrescentado relatos seus em terceira pessoa $(3.1-32 ; 11.1-2 ; 12.44-47 ; 12.44-13.3)$, no intuito de recontar a história de Israel: passado, presente e futuro. É assim que 1 e 2 Crônicas são compostos, para adicionar as "coisas omitidas" (paralipômenon), como a Septuaginta os chama. O que, na verdade, exclui tudo o que é de Israel Norte e enaltece Judá, tendo como figura central o rei Davi governando as doze tribos. O cronista escreve livremente utilizando informações do Pentateuco e dos livros históricos, omite todos os atos negativos de Davi e acrescenta à sua maneira aspectos de seu interesse. Relata uma história sagrada do passado, na qual exalta os heróis de Judá e exclui os de Israel Norte; descreve o presente, sublimando a proeminência de Esdras e Neemias e a pureza da Golah, e projeta um reino futuro construído sobre a Lei (Torá). É nesse conjunto ideológico que devem ser lidos os livros de Neemias, Esdras e Crônicas, que parece ser a ideologia da nação santa, povo eleito, hasmoneia. ${ }^{14}$

\section{O contexto histórico de Neemias e o vazio arqueológico do período persa: um debate em aberto}

Para o MHC é relevante o estudo do contexto histórico dos textos bíblicos, mais que isso, o contexto histórico é parte intrínseca ao MHC. Situar o texto bíblico em seu contexto histórico é fundamental para a compreensão do seu conteúdo. No nosso caso, o objeto a perseguir é o contexto histórico do livro de Neemias, ou seja, em que período os textos de Neemias e, por extensão, de Esdras, surgiram. Isso é relevante, pois é comum na pesquisa bíblica situar não somente os livros de Esdras e

\footnotetext{
${ }^{14}$ Essa ideologia também é encontrada nos livros de Ageu, Zacarias, Eclesiástico e 1 e 2 Macabeus. Cf. o elogio a Neemias em Eclo 49.13.
} 
Neemias, mas também grande parte da produção bíblica no período persa. ${ }^{15}$ Mas será essa a última palavra? Vejamos o que diz a arqueologia.

\section{Jerusalém e o contexto arqueológico}

É de conhecimento comum a atual dificuldade, principalmente por questões político-religiosas, para se escavar a Jerusalém antiga, que se encontra quase toda ela enquadrada pela muralha turco-otomana construída por Solimão o Magnífico (15201566). Contudo, há certo consenso desde a década de 1960, quando as escavações na cidade ainda eram bastante viáveis, que a Jerusalém dos períodos persa (538-533) e helenista antigo (333-135) ${ }^{16}$ não se estendeu para a cidade alta. Tradicionalmente, sua localização é atribuída à área denominada de "a cidade de Davi"17, apesar de não haver remanescentes arquitetônicos e de o achado de artefatos arqueológicos desse período ser praticamente inexistente.

Atualmente uma equipe do Departamento de Arqueologia da Universidade de Tel Aviv, coordenada pelo arqueólogo Yuval Gadot, está realizando escavações numa pequena área conhecida como Givati Parking Lot, no lado noroeste da cidade antiga, no bairro judaico. A escavação, que em visita pessoal na temporada de 2018 já havia atingido em torno de dez metros de profundidade, até o extrato do Ferro II, encontrou significativo material dos períodos bizantinos, romano, helenista tardio, mas somente pouco e pequenos pedaços de cerâmica do período grego inicial e persa. ${ }^{18}$ Recentemente foi destaque na mídia internacional o selo encontrado nesse local. O selo contém uma bula com o seguinte dizer: Natan-Melek ebed hamelek (Natan-Melek, servo/ ministro do rei). Uma vez que o selo tenha sido encontrado no extrato pertencente ao Ferro II tardio, final do século VII a.C., é possível que pertencesse ao eunuco do rei Josias, Natã-Melek, mencionado em 2 Reis 23.11. ${ }^{19}$

Também foram escavados pequenos pontos ao redor do Givati Parking, que cobrem uma área três vezes maior que o Givati Parking, mas também ali não foi encontrado nada, nem cerâmica persa nem helenista antigo. Costuma-se encontrar, com relativa abundância, artefatos do período bizantino, romano tardio, romano antigo e helenista tardio. Depois do helenista tardio aparece imediatamente o estrato do período do Ferro II Tardio (final da monarquia). Todo o conjunto dos períodos helenista antigo e persa está faltando. É como se esses estratos não existissem.

${ }^{15}$ Cf. ALBERTZ, Rainer. A History of Israelite Religion in the Old Testament Period - From the Exile to the Maccabees. Lousville: Westminster John Knox Press, 1994. v. II, p. 164-523.

${ }^{16}$ Divide-se o período helenista em: período helenista antigo (333-135), quando Judá estava sob o domínio ptolomaico e selêucida, e período helenista tardio (135-63), quando Judá era governada pela dinastia hasmoneia.

17 O’CONNOR, Jerome Murphy. Tierra Santa - Desde los Orígenes hasta 1700. Madrid: Acento editorial, 2000. p. 108-115.

18 GADOT, Yuval et al. New studies in the Archaeology of Jerusalem and its region. Tel Aviv: Tel Aviv University, 2017.

19 Cf. <https:/www.jewishpress.com/news/israel/jerusalem/seal-bearing-name-of-king-josiahs-court-officialuncovered-in-city-of-david/2019/03/31/>. Acesso em: 10 jul. 2019. 
Curiosamente, essa é a mesma situação do século $\mathrm{X}$ a.C., que é o período atribuído aos reinados de Davi e Salomão. Até hoje também não foi encontrado nada expressivo desse período em Jerusalém, nem templo nem muralha nem palácio.

A falta de sinais da cidade do período persa e helenista antigo (e por extensão do período do século X) costuma ser atribuída ao fato de a cidade estar situada num monte, posição que favorece a erosão, a qual teria destruído possíveis estruturas remanescentes da cidade. $\mathrm{Ou}$, então, que, devido às constantes destruições e reconstruções de séculos, não seja mais possível encontrar sinais da cidade desses períodos. Também é bem verdade que durante os períodos persa e helenista antigo não houve guerra em Jerusalém, portanto não houve destruição, e a arqueologia, para fazer sua leitura, beneficia-se da destruição. Mas, ainda assim, se houve assentamento, é factível que se encontrem alguns artefatos também de períodos em que não houve destruição. Além do mais, como diz Israel Finkelstein (em conversa pessoal), muros e pisos não podem evaporar ou simplesmente desaparecer no ar. Se assim fosse, também não se deveriam encontrar remanescentes arquitetônicos de outros períodos.

Para Finkelstein, a única solução para esse "incômodo vazio" é de que os assentamentos do século $\mathrm{X}$ e dos períodos persa e helenista antigo se encontrem sob a esplanada do templo (Haram ash-Sharif). ${ }^{20}$

Em nossa recente visita de estudos a Jerusalém, o guia relatava ${ }^{21}$ que a comunidade palestina havia feito uma reforma junto ao portão dos leões, também conhecido como portão de Santo Estêvão, que fica na parte leste da cidade, bem próximo ao Haram ash-Sharif (esplanada do templo). Vários caminhões de terra teriam sido retirados e levados para fora da cidade. Alguns arqueólogos israelenses teriam aproveitado a oportunidade e peneirado toda a terra, em busca de material arqueológico. Contudo, muito pouco teria sido encontrado e a maior parte era dos períodos do Ferro e helenista tardio.

Em todo caso, em nosso entender, se foi encontrada alguma cerâmica, por pouco que seja, é sinal de que na atual Jerusalém antiga havia um assentamento no período persa e helenista antigo. Ou seja, para a arqueologia, a Jerusalém do período persa e helenista antigo, com o seu templo, cujos remanescentes devem estar sob o Haram ash-Sharif, deveria ser "estranhamente" pequena e muito pobre.

\section{A província Jehud do período persa}

Paralelo ao assunto da ocupação de Jerusalém está o da extensão da província Jehud do período persa. Qual era o tamanho de Judá durante o período persa? Essa resposta é hoje possível graças ao mapeamento geográfico feito por uma equipe de arqueólogos da Universidade de Tel Aviv, coordenada por Oded Lipchits e David Wanderhuff, do Boston College (EUA). Após escavar o sítio arqueológico de Ramat Rahel,

\footnotetext{
${ }^{20}$ A esplanada ou Haram ash-Sharif é uma obra gigantesca realizada por Herodes o Grande (37-04), que cortou o topo do monte Sião e aterrou as partes laterais até atingir uma forma perfeitamente plana.

${ }^{21}$ Confirmado também por Israel Finkelstein em conversa pessoal.
} 
a equipe fez um levantamento dos potes de cerâmica com selos Jehud Parvak (Província de Judá) impressos na alça do período persa e encontrados em Judá. ${ }^{22}$ Com isso puderam entender até onde ia a extensão da Judeia desse período. A conclusão foi surpreendente: $85 \%$ dos selos Jehud Parvak foi encontrado nos arredores de Jerusalém, particularmente em Ramat Rahel, que dista $4 \mathrm{~km}$ de Jerusalém, onde estava a expressiva maior parte. E 90\% dos selos, se incluir Masfa de Benjamin, que dista cerca de 10 quilômetros ao norte de Jerusalém. ${ }^{23}$ Ou seja, a província Jehud do período persa não era muito maior do que é hoje a cidade moderna de Jerusalém, seguindo em direção norte até Masfa (Tell en-Nasbeh). Portanto uma área muito menor do que se supunha.

\section{Ramat Rahel e não Jerusalém}

Como dito acima, o sítio arqueológico Ramat Rahel se encontra a $4 \mathrm{~km}$ ao sul da Jerusalém antiga e a meio caminho entre Jerusalém e Belém. É a área que na Bíblia é conhecida como o "Vale dos Reis" e, ao que tudo indica, era uma espécie de propriedade privada da dinastia davídica (Gn 14.17; 2Sm 18.18). O primeiro a escavar o sítio foi Yohanan Aharoni, em 1954 e em 1959-1962. Quarenta e três anos mais tarde, de 2005 a 2010, as escavações foram retomadas pela Universidade de Tel Aviv, em parceria com a Universidade de Heidelberg, Alemanha, sob a coordenação dos arqueólogos Oded Lipschits e Manfred Oeming. ${ }^{24}$

Apesar de ser um sítio muito pequeno, mas muito bem protegido, Ramat Rahel tinha uma função extremamente importante. Tudo girava em torno do enorme e bem construído edifício escavado inicialmente por Aharoni e mais tarde completado por Lipschts e Oeming. O edifício não era nada mais e nada menos que um grande centro de coleta de tributos de Judá. A quantidade de cerâmica encontrada no lixão de Ramat Rahel é impressionante. Segundo Lipschits, em nenhum lugar no mundo foram encontrados tantos jarros de cerâmica para a coleta de tributos como em Ramat Rahel. ${ }^{25}$ A grande surpresa é que esse sítio esteve ativo e cumprindo plenamente sua função por 600 anos. ${ }^{26} \mathrm{Ou}$ seja, desde o domínio assírio, em 705 a.C., até o reinado hasmoneu, em 135 a.C., quando foi destruído.

Em síntese, depois de perder Laquis, que foi destruída por Senaquerib em 705, e que até então era o centro da coleta de tributo de Judá, a Assíria construiu um novo centro tributário para Judá, que foi Ramat Rahel. Com a chegada dos babilônios, no final do século VII, Ramat Rahel continuou cumprindo a mesma função. Os babilônios,

22 Os potes com selo na alça representa o tributo recolhido pela província Jehud para a Pérsia, o que por sua vez revela até onde chegava o limite do seu território.

${ }^{23}$ LIPSCHITS, Oded; VANDERHOOFT, David. The Yehud Stamp Impressions: A Corpus of Inscribed Impressions from the Persian and Hellenistic Periods in Judah. Winona Lake: Eisenbrauns, 2011.

${ }^{24}$ LIPSCHITS, Oded et al. Palace and Village, Paradise and Oblivion: Unraveling the Riddles of Ramat Rahel. Near Eastern Archaeology, Chicago, v. 74, n. 1, p. 1-48, 2011

${ }^{25}$ LIPSCHITS, Oded et al. What Are the Stones Whispering? Ramat Rahel: 3000 Years of Forgotten History. Winona Lake: Eisenbrauns, 2017. p. 82-83.

${ }^{26}$ LIPSCHITS et al., 2017, p. 3-4. 
ademais, ampliaram o edifício e fizeram dele um impressionante palácio, de forma que, além de centro da coleta de tributo, Ramat Rahel se tornou também um local de reuniões e festas da elite da província Jehud.

Quando Jerusalém foi destruída em 587 a.C., Ramat Rahel continuou funcionando normalmente, sem mudança. Foram encontrados 250 mil pedaços de cerâmica desse período. ${ }^{27}$ Masfa (Tell en-Nasbeh) passou a ser o lugar do governo e Ramat Rahel continuou sendo o lugar da coleta de tributos. Ela foi destruída somente por volta de 135 a.C., provavelmente por João Hircano. Portanto, com a descoberta de Ramat Rahel, é hoje seguro afirmar que o centro da coleta de tributos não era Jerusalém, como sempre se supunha, mas Ramat Rahel. E o curioso de tudo isso é que Ramat Rahel não é mencionada na Bíblia e, por isso, desconhecida até há pouco tempo. Esse silêncio sobre Ramat Rahel na Bíblia, particularmente nos livros de Esdras e Neemias, é sem dúvida sintomático.

\section{A ausência de escritos extrabíblicos do período persa ${ }^{28}$}

Como já mencionado acima, grande parte da produção da literatura bíblica costuma ser situada no período persa. Contudo, por estranho que pareça, fora da Bíblia até hoje não foi encontrado nenhum escrito em toda Judá do período persa. Foram encontradas algumas moedas, mas, como diz Finkelstein, moedas não comprovam a existência de atividade literária. ${ }^{29} \mathrm{O}$ que temos do período persa, isso fora de Judá, são os papiros de Elefantina, onde consta uma carta de Bagohi dirigida ao governador persa pedindo auxílio para a construção do templo na ilha de Elefantina. ${ }^{30}$ Essa é uma referência importante, pois confirma a existência de um núcleo antigo das memórias de Neemias na composição do livro.

$\mathrm{O}$ que é relativamente seguro é de que temos grande atividade literária em Judá no final da monarquia, século oitavo e sétimo, comprovado pelo estudo feito dos ôstracos de Arad. Nesse particular, um grupo do departamento de arqueologia da universidade de Tel Aviv, que trabalha com epigrafia digita ${ }^{31}$, descobriu a presença de cinco a seis caligrafias diferentes nos ôstracos. Ou seja, cinco a seis pessoas diferentes escreveram os ôstracos, o que prova que a região de Arad tinha, por volta do século sétimo a.C., uma escola de escribas. Isso é interessante, pois Arad, localizada na fronteira com o deserto de Judá, não era a localidade mais importante de Judá nesse período. Se considerarmos outros centros, como Laquis e Jerusalém, o número deveria ser bem maior.

${ }^{27}$ LIPSCHITS et al., 2011, p. 2-49.

${ }^{28}$ Essa parte terá como referencial principal os diversos artigos publicados por Israel Finkelstein acerca do contexto de Judá no período persa.

${ }^{29}$ FINKELSTEIN, Israel. Jerusalem in the Persian (and Early Hellenistic) Period and the wall of Nehemiah. JSOT, Chicago, v. 32, n. 4, p. 501-520, 2008.

${ }^{30}$ PORTEN, Bezalel. The Elephantine Papyri in English - Three Millennia of Cross-Cultural Continuity and Change. Atlanta: Society of Biblical Literature, 1996.

${ }^{31}$ Ciências que estudam as inscrições em monumentos e artefatos antigos. 
Depois do exílio, a atividade literária em Judá volta a ser intensa somente no final do período helenista, segunda metade do segundo século a.C., que se ajusta com o reinado hasmoneu. Portanto, pelas evidências arqueológicas, a atividade literária em Judá declinou expressivamente no período persa.

\section{Textos bíblicos para iluminar essa realidade}

O MHC prioriza a leitura diacrônica dos textos bíblicos, na qual se valoriza a existência de possíveis camadas redacionais. Esse parece ser o caso do livro de Neemias, onde, provavelmente, há um antigo núcleo que traz as memórias do personagem Neemias. A partir desse núcleo foi sendo gestado o livro de Neemias, que possivelmente recebeu sua forma final no período hasmoneu.

Como a arqueologia pode contribuir para descortinar o contexto histórico que se encontra por trás do conteúdo do livro de Neemias? Pelo caráter geográfico do livro de Neemias. Isto é, grande parte do conteúdo de Neemias faz referência a lugares, cidades, regiões etc. Isso permite que o pesquisador possa comparar o conteúdo do texto com os resultados da arqueologia, se tinha ou não assentamento e ou grandes construções na época a que o texto se refere. É a partir desse princípio que se fará a análise dos textos a seguir.

\section{Neemias 3.1-32: A reconstrução da muralha de Jerusalém}

Um dos textos paradigmáticos do livro de Neemias é Neemias 3.1-32, que trata da reconstrução da muralha de Jerusalém. $O$ texto relata com detalhes como cada parte da muralha foi sendo reconstruída e quem dela participou ou não participou. $\mathrm{O}$ relato começa no portão das ovelhas (v. 1), segue todo o entorno da cidade, passando pelas torres e pelos demais portões, até chegar novamente ao portão dos peixes (v. 32). Ou seja, as referências são claras, de quem conhece a muralha no momento da escrita. Pela descrição parece não haver dúvida de que se trata da grande muralha de Jerusalém. Até aí, tudo bem. O texto é claro e o objeto descrito também. Onde está o problema? O problema está no fato de que não existe muralha do período persa. A única muralha existente, encontrada após um século de escavações, é a muralha hasmoneia, do período helenista tardio. Essa muralha segue praticamente a mesma base da muralha destruída em $586 / 7$ pela Babilônia. ${ }^{32}$

Outra questão são as cidades mencionadas, cuja população auxiliou na reconstrução da muralha. Por exemplo, a menção a Gabaon (v. 7) e ao distrito de Betsur ${ }^{33}$ (v. 16). Segundo Finkelstein, Betsur não tinha fortificações no período persa e helenista antigo, talvez tivesse um pequeno assentamento. $\mathrm{O}$ mesmo vale para Gabaon, que tinha assentamento no século VI, mas não nos séculos V ao III. Gabaon só volta a ser habitada a partir do século II. Também não tem nada ao redor de Jericó (v. 2) nem na

\footnotetext{
32 FINKELSTEIN, 2008, p. 501-520.

33 (Bet-sur), a nomenclatura é tomada da Bíblia de Jerusalém.
} 
Sefelá. ${ }^{34}$ Ou seja, como visto acima, a Jehud do período persa parece não corresponder à Judeia de Neemias 3.1-32. O que não quer dizer que no livro de Neemias não exista material mais antigo acerca da muralha, como se pode ver em Neemias 1.3 e 2.3-8. Contudo, as informações ali são sempre genéricas, fala-se basicamente somente da necessidade de se reconstruir a muralha.

Tudo isso parece evidenciar que por trás do texto de Neemias 3.1-32 está a realidade hasmoneia, ou seja, a muralha a que o texto se refere é a muralha hasmoneia.

Situação similar aos detalhes da muralha e das localidades pode ser visto na referência aos inimigos de Neemias, mencionados em Neemias 2.19 e 4.1,7-8. ${ }^{35}$ Nesses textos, que parecem mais recentes, os inimigos são identificados com nome, mas noutros, que parecem mais antigos, como em 6.16, a menção aos inimigos de Neemias é genérica, sem identificação. Além disso, cabe perguntar: o que Neemias e a pequena comunidade renascente de Jerusalém têm a ver com os samaritanos, os árabes, os amonitas e os asdotitas, tão longe de Jerusalém? O que Neemias tem a ver com Asdod, que fica na costa do mar Mediterrâneo; com Amon, que fica do outro lado do Jordão; com Samaria, que fica distante no norte; e a Arábia do deserto sul? Não obstante, esses povos representam exatamente as quatro direções da expansão hasmoneia na segunda metade do século II a.C., como pode ser visto no livro de Primeiro Macabeus: os árabes no sul, os samaritanos no norte, os amonitas no leste e os asdoditas no oeste. Curiosamente, Neemias aparece em Segundo Macabeus como uma figura proeminente (2Mac 1.18,20,21,23,31,33,36; 2.13; cf. Eclo 49.15). Por que ele é tão importante para os macabeus, pergunta Finkelstein? Possivelmente porque Neemias não era da realeza davídica, como os hasmoneus, e, por isso, era mais bem aceito por eles.

\section{Neemias 7.6-72 e a lista dos repatriados}

No mesmo plano da muralha, das localidades e dos adversários de Neemias, encontra-se a famosa lista dos que regressaram do exílio da Babilônia (Ne 7.6-72), conhecidos como o grupo da golah. Essa mesma lista se encontra em Esdras 2.1-70, sem diferença. Finkelstein listou todos os lugares que ali são mencionados (Ne 7.2638), que são possíveis de identificar e que podem ser checados pela arqueologia: ${ }^{36} \mathrm{Ga}-$ baon, Belém, Anatot, Bet-Azmot, Cariat-Iarim, Cafira, Beerot, Ramá, Gaba, Macmas, Betel, Hai, Jericó, Lod, Hadid e Ono. ${ }^{37}$ Todos esses sítios tinham forte atividade no período do Ferro II e forte ou meio forte atividade no período helenista tardio. Contudo, no período persa, alguns não tinham nenhuma atividade e outros tinham atividade fraca. Ou seja, alguns eram inexistentes e outros tinham um pequeno assentamento.

\footnotetext{
${ }^{34}$ FINKELSTEIN, 2008, p. 501-520.

${ }^{35}$ FINKELSTEIN, Israel. Nehemiah's adversaries: A hasmonaean reality? Transeu, v. 47, 2015, p. 47-55. Disponível em: <https:/www.academia.edu/30105351/Nehemiahs_adversaries_A_Hasmonaean_ Reality/>. Acesso em: 09 jul. 2019.

${ }^{36}$ FINKELSTEIN, Israel. Archaeology and the list of returnees in the books of Ezra and Nehemiah. Palestine Exploration Quarterly, Tel Aviv, v. 140, n. 1, p. 1-10, 2008.

37 Segui a nomenclatura da Bíblia de Jerusalém.
} 
Por exemplo, sítios como Gabaon e Anatot, fortes no Ferro II, não apresentam nenhuma evidência de ocupação no período persa. Além disso, por que somente as áreas de Benjamin e Lod estão representadas? E por que os sítios, onde foi encontrado o maior número de selos da Jehud persa, como Masfa, Ein Gedi e Ramat Rahel, estão ausentes no texto, pergunta Finkelstein? ${ }^{38}$ De fato, por que Ramat Rahel, um sítio tão importante no período persa e destruído somente no segundo século a.C., provavelmente pelos hasmoneus, não é mencionado na Bíblia? Por outro lado, parte dos sítios mencionados na lista aparece nos livros dos Macabeus, inclusive, são cidades de grande importância na história dos hasmoneus, como, Beerot, Macmas e Hadid.

Se observarmos bem, a distribuição geográfica das listas da genealogia vai do sul de Hebron até Siquém, no norte; da Sefelá, no oeste, até Nebo, Baal-Meon e Mádaba, na Transjordânia, no leste. De acordo com a distribuição dos selos Jehud do período persa, visto acima, essa área não fazia parte da província Jehud. Portanto a lista de Neemias 7.6-72 e Esdras 2.1-70 parece não corresponder à geografia da Jehud persa.

Porém, no século II, a partir dos anos 160 a.C., e mais intensamente no final do segundo século, com Jônatas (160-143), com Simão (143-134) e, por fim, com João Hircano (134-104), a extensão territorial de Judá muda completamente. O estado hasmoneu se estende de Hebron, no sul, até Siquém, no norte, onde destrói o templo samaritano no monte Geresim; e da Sefelá, na costa oeste, até o além Jordão, onde conquista Moab. Portanto a lista genealógica de Neemias 7.6-72 e Esdras 2.1-70 representa exatamente a ocupação do estado hasmoneu. É também mais ou menos o território atribuído ao domínio davídico na suposta monarquia unida.

Segundo Finkelstein, esses territórios tinham pouca presença judaíta e precisavam ser legitimados para a ocupação hasmoneia. ${ }^{39}$ Assim, construiu-se uma legitimação genealógica retrocedendo ao período monárquico, fundamentada na descendência tribal. Essa mesma legitimação se encontra no livro dos Jubileus e no Testamento das Doze Tribos, escritos nesse período. O curioso é que também as cidades conquistadas e fortificadas por Roboão, listadas em 2 Crônicas 11.5-12,23, correspondem à expansão hasmoneia de João Hircano. ${ }^{40} \mathrm{E}$ o mais curioso é que elas não se encontram no livro de 2 Reis, onde o cronista se inspirou (2Rs 12.21-21;14.21-31). Ou seja, o cronista acrescentou na conquista de Roboão as cidades conquistadas pelos hasmoneus. $\mathrm{O}$ que vale dizer que Neemias, Esdras e Crônicas são livros hasmoneus ou, pelo menos, contêm material do período hasmoneu, e todos têm a mão do cronista.

Diante de tudo isso, Finkelstein afirma que temos duas saídas: uma, situar o máximo possível de material bíblico no final da monarquia e no exílio; outra, situar mais produção bíblica no período hasmoneu. Não pensamos exatamente assim, ainda que entendamos que houvesse grande produção no final da monarquia, sétimo século a.C., e durante o exílio, assim como durante o período hasmoneu. Porém também é

${ }^{38}$ FINKELSTEIN, 2008, p. 1-10.

${ }^{39}$ FINKELSTEIN, Israel. The Expansion of Judah in II Chronicles: Territorial Legitimation for the Hasmoneans? Zeitschrift für die Alttestamentliche Wissenschaft, Berlin, v. 127, p. 669-695, 2015.

${ }^{40}$ FINKELSTEIN, Israel. Rohoboam's Fortresses Cities (II Chr 11,5-12): A Hasmonean Reality. Zeitschrift für die Alttestamentliche Wissenschaft, Berlin, v. 123, p. 92-107, 2011. 
acertado pensar que houve produção de literatura bíblica no período persa, principalmente mais para o final persa e início helenista, antes da chegada dos hasmoneus. No entanto, é preciso reconhecer que a comunidade judaíta de Jerusalém não era tão grande e tão forte como se supunha. Definitivamente, depois da descoberta de Ramat Rahel, o templo de Jerusalém não pode mais ser considerado o centro da coleta de tributo do período persa. Ademais, não dá para ocultar a ausência do estrato persa. Não se pode ignorar a carência de monumentos e de cerâmica dessa época. Portanto a Jerusalém persa devia ser uma comunidade bastante pobre, particularmente pela falta de assistência do Estado. O templo, de certa forma, parece ter sido um poder paralelo, que sobrevivia à custa de doações e ofertas da comunidade religiosa. Mas isso não impossibilita que a comunidade jerusalemita pudesse produzir escritos. Se a comunidade no exílio, com todas as limitações, conseguiu produzir grande quantidade de textos, por que a comunidade de Jerusalém, com muito mais liberdade e autonomia, não poderia fazê-lo? Pensamos particularmente em textos como o livro de Daniel, Sirácida, Eclesiastes etc., que, de certa forma, foram a sustentação teórica da revolta macabeia, a qual culminou na dinastia hasmoneia. Contudo, entendemos que devemos começar a olhar com maior atenção para a produção do período hasmoneu, quando Judá, por primeira vez na história, se torna um país independente, consolida um Estado e conquista uma extensão territorial como jamais antes. A teologia nacionalista presente nos livros de Neemias, Esdras e Crônicas é marca desse reinado.

\section{Considerações finais}

Até o presente momento não tem surgido um método que suprisse à altura o MHC. De forma que, ainda que aberto a outros métodos e abordagens, no intuito de complementar o MHC, seguimos tendo-o como bússola em nossos estudos bíblicos, principalmente no que tange à análise diacrônica dos textos. No presente artigo tomamos como ajunto do MHC o diagnóstico do que denominamos de a nova arqueologia, que se caracteriza basicamente pela leitura crítica da realidade por meio das evidências arqueológicas.

Guiados pelo MHC e pela nova arqueologia, tendo como base principal os artigos de Finkelstein, Lipschits e Gadot, foi visto que há um grande vazio arqueológico da Jerusalém dos períodos persa e helenista antigo. Ou seja, até hoje não foram encontrados artefatos relevantes em Jerusalém, o que coloca uma grande interrogante sobre a dimensão da cidade desses períodos, que, pelas referências, era bastante pobre, assim como o seu templo. Da mesma forma, após a escavação de Ramat Rahel e do estudo das pitoi, grandes jarros para a coleta de tributo, encontrados no território de Judá, comprova-se que a Jehud persa compreendia um território bastante reduzido. Ademais, que o centro da coleta de tributo não era o templo de Jerusalém, mas Ramat Rahel.

Os textos bíblicos analisados parecem confirmar essa tendência. É o caso de Neemias 3, que trata da reconstrução da muralha de Jerusalém, que, pela descrição do texto, trata-se da muralha hasmoneia construída no final do século II a.C. Da mesma forma, as localidades mencionadas no livro de Neemias não correspondem ao período 
persa, pois a maioria não tinha assentamento nessa época. Essa descrição também parece ser ratificada pela referência aos inimigos de Neemias mencionados no texto, que, como na lista dos repatriados ( $\mathrm{Ne} 7$ ), são os mesmos povos conquistados pela política expansionista do reinado hasmoneu. Ou seja, a Jehud do período persa parece não corresponder à Judá do livro de Neemias. É provável que por trás da redação final do livro de Neemias esteja a realidade hasmoneia. Sem contar que as referências cronológicas do conjunto dos livros de Esdras e Neemias são bastante confusas.

Tudo isso acarreta um grande questionamento para a pesquisa moderna, que tende a situar grande quantidade de literatura bíblica como tendo sido composta no período persa. Ademais, pelas evidências arqueológicas, a escrita em Judá parece ter declinado nesse período.

\section{Referências}

ALBERTZ, Rainer. A History of Israelite Religion in the Old Testament Period - From the Exile to the Maccabees. Lousville: Westminster John Knox, 1994. v. II, p. 164-523.

BÍBLIA DE JERUSALÉM. São Paulo: Paulus, 2002. p. 547-549.

DAVIS, W. Thomas. Shifting Sands: The Rise and Fall of Biblical Archaeology. New York: Oxford University Press, 2004.

FINKELSTEIN, Israel. The Stratigraphy and Chronology of Megiddo and Bethshan in the 1211th Centuries B.C.E. Tel Aviv, v. 23, p. 170-184, 1996.

FINKELSTEIN, Israel. The Expansion of Judah in II Chronicles: Territorial Legitimation for the Hasmoneans? Zeitschrift für die Alttestamentliche Wissenschaft, Berlin, v. 127, p. 669-695, 2015. FINKELSTEIN, Israel. Rohoboam's Fortresses Cities (II Chr 11,5-12): A Hasmonean Reality. Zeitschrift für die Alttestamentliche Wissenschaft, Berlin, v. 123, p. 92-107, 2011.

FINKELSTEIN, Israel. Jerusalem in the Persian (and Early Hellenistic) Period and the wall of Nehemiah. JSOT, Chicago, v. 32, n. 4, p. 501-520, 2008.

FINKELSTEIN, Israel. Archaeology and the list of returnees in the books of Ezra and Nehemiah. Palestine Exploration Quarterly, Tel Aviv, v. 140, n. 1, p. 1-10, 2008.

FINKELSTEIN, Israel. Nehemiah's adversaries: A hasmonaean reality? Transeu, v. 47, p. 47-55, 2015. Disponível em: $<$ https://www.academia.edu/30105351/Nehemiahs_adversaries_A_Hasmonaean_Reality/>. Acesso em: 09 jul. 2019.

FITZMYER, Joseph A. A Bíblia na Igreja. São Paulo: Loyola, 1997.

GADOT, Yuval et al. New studies in the Archaeology of Jerusalem and its region. Tel Aviv: Tel Aviv University, 2017.

KAEFER, José Ademar. Arqueologia das Terras da Bíblia. São Paulo: Paulus, 2016. v. II.

KAEFER, José Ademar. Hermenêutica bíblica: Refazendo caminhos. Estudos de Religião, São Bernardo do Campo, v. 28, n. 1, p. 115-134, 2014.

LIPSCHITS, Oded; VANDERHOOFT, David S. The Yehud Stamp Impressions: A Corpus of Inscribed Impressions from the Persian and Hellenistic Periods in Judah. Winona Lake: Eisenbrauns, 2011.

LIPSCHITS, Oded et al. Palace and Village, Paradise and Oblivion: Unraveling the Riddles of Ramat Rahel. Near Eastern Archaeology, Chicago, v. 74, n. 1, p. 1-48, 2011.

LIPSCHITS, Oded et al. What Are the Stones Whispering? Ramat Rahel: 3000 Years of Forgotten History. Winona Lake: Eisenbrauns, 2017.

O’CONNOR, J. M. Tierra Santa - Desde los Orígenes hasta 1700. Madrid: Acento editorial, 2000. 
PONTIFÍCIA COMISSÃO BÍBLICA. A interpretação da Bíblia na Igreja. São Paulo: Paulinas, 1994. n. 134.

PORTEN, Bezalel. The Elephantine Papyri in English - Three Millennia of Cross-Cultural Continuity and Change. Atlanta: Society of Biblical Literature, 1996.

RÖMER, Thomas; MACCHI, Jean-Daniel; NIHAN, Christophe (Orgs.). Antigo Testamento: história, escritura e teologia. São Paulo: Loyola, 2010.

STEINS, Georg. Os livros de Esdras e Neemias. In: ZENGER, Erich (Org.). Introdução ao Antigo Testamento. São Paulo: Loyola, 2003. p. 222-232.

USSISHKIN, David. Megiddo-Armageddon. The Story of the Canaanite and Israelite City. Jerusalém: Israel Exploration Society, 2018. Disponível em: <https://www.jewishpress.com/ news/israel/jerusalem/seal-bearing-name-of-king-josiahs-court-official-uncovered-in-city-of-david/2019/03/31/>. Acesso em: 10 jul. 2019. 